\title{
Incidence of diabetes mellitus in Oslo, Norway 1956-65
}

\author{
HANS JACOB USTVEDT AND ERNST OLSEN \\ From the Life Insurance Companies' Institute for Medical Statistics at the Oslo City Hospitals
}

SUMMARY A study of the incidence of diabetes mellitus in Oslo for the period 1925-54 (Westlund, 1966), based on a comprehensive compilation of hospital documents, has been extended to $1956-65$. The incidence rates for the two periods have been compared, by taking the year of diagnosis and age at diagnosis in each case. The incidence rates for 1925-54 were revised by adding cases for this period discovered during the 1956-65 study, and showed no major changes. In particular, few new cases were found that had been diagnosed during the second world war, so that the dramatic reduction in incidence shown in Westlund's paper is not affected. The trend is fairly constant, with two exceptions: there was an increase in incidence for boys and girls younger than 10 years and a decrease for women aged between 40 and 59 years. After considering the various sources of error in such a comparison it is concluded that since 1950 there may have been a real increase in rates of diabetes in children. The decrease in rates for middle-aged women is not supported by mortality data for which statistics are given for associated as well as for underlying causes. Mortality data are however difficult to interpret, and by relying on hospital documents and death certificates considerably higher incidence rates have been presented than would have been the case had the incidence estimations been based on death certificates alone. The incidence rates in 1956-64 for children tally fairly well with those reported for Great Britain and Ireland (Bloom et al., 1975) and for northern Norway (Bratlid, 1976).

In 1966 a study of the incidence of diabetes mellitus in Oslo was published (Westlund, 1966), based on a comprehensive compilation of hospital documents for the period 1925-55. The main purpose was to study the fluctuations of incidence in relation to the second world war, taking the year of diagnosis and the age at diagnosis in each case.

It was assumed in making such an epidemiological reconstruction that sooner or later nearly all persons with diabetes will visit a hospital and be discharged (alive or dead) with diabetes as one of the diagnoses. Of course, in some cases the delay between diagnosis and first hospital discharge may be long. However, Westlund found that $85 \%$ of all persons dying in Oslo during 1951-55 with diabetes mellitus mentioned on the death certificate had been recorded between 1925 and 1955 by the hospital, which suggests a completeness adequate for at least some purposes.

The present study extends the period of compilation to cover the years 1956-65, and the epidemiological technique has been as close to that used by Westlund as possible. The purpose was:
To quantify the deficiencies in incidence rates computed by Westlund caused by delays in the first admittance to hospital of cases actually diagnosed during the years on which he reported.

To determine whether the incidence of diabetes has been increasing in recent decades, and if so, in which age and sex groups.

To make a register of diabetics in hospital for the first time so as to follow-up mortality, particularly cardiovascular mortality, of patients discharged on oral drugs.

The mortality of the recorded patients was followed until 1973, and will be reported later.

\section{Material and methods}

Data were collected from 14 departments of internal medicine or paediatrics in Oslo-that is, from all official or semiofficial hospitals in the area. The names of 3368 patients discharged with a diagnosis of diabetes were recorded for the years 1956-65, excluding patients who had earlier been recorded in 1925-55. The hospital records were then located and information was extracted. 
The hospital records could not be found for 102 cases $(3 \%)$ in spite of great efforts. Most of these were of patients over 60 years of age.

One hundred and eleven patients were excluded because they were found not to have resided in Oslo at the time of admission to hospital. A further 282 patients were excluded because they were first diagnosed as diabetics at a hospital which was not included in the study or in hospital departments not included-such as departments of surgery. In most of these it would not have been possible to ascertain the year of diagnosis of diabetes. Some of these patients would in all likelihood not have been living in Oslo at the time of first admission. Fourteen patients were omitted for special reasons.

Included were 2859 Oslo citizens who had been first discharged from hospital with a diagnosis of diabetes during the period 1956-65. Of these 237 had been diagnosed between 1925 and 1954 without being admitted to hospital and were therefore used to amplify Westlund's follow-up study. Three had been diagnosed before 1925, and six in 1955. Out of a total of 2859 patients 140 $(5 \%)$ were younger than 20 years.

To prepare incidence estimates the year of diagnosis and the age at diagnosis were used for each patient. Patients diagnosed before 1956 or after 1964 were thus not taken into account in calculating the rate for the period 1956-64. Details of the population in Oslo, distributed by sex and age for each of the years between 1956 and 1964 were obtained from the Municipal Office of Statistics.

Table 1 shows that $85 \%$ of the males below the age of 20 , and $75 \%$ of the females below 20 years consulted doctors because of symptoms or complications of diabetes. In cases in which diabetes was discovered in connection with some other disease or injury, or by a health check, clinical symptoms were present in some of these, and the diagnosis was based on glycosuria and repeated fasting blood sugar values (above $130 \mathrm{mg} / 100 \mathrm{ml}$ ), sometimes this was combined with a pathological blood sugar curve on tolerance test. Borderline cases were excluded. If two or more diagnoses were recorded in the hospital records it seemed to be a matter of choice whether diabetes was the main or the subsidiary diagnosis.

It has not been possible to estimate the percentage of diabetics who have never been admitted to hospital. Consultants and doctors in private practice who treat a large number of diabetics agree that practically all patients below the age of 30 years with recently detected diabetes will have been admitted to hospital; but for patients aged 30-59 years hospital admission may not always have been necessary, and this applies particularly to patients above 60 years who would often be admitted later for other diseases or for diabetic complications.

This bias in underestimating incidence of first diagnosis will, of course, be greater for the more recent years. In particular, many patients who were first diagnosed during the last year of the period of registration will be missed. Accordingly Westlund restricted incidence computations from his 1925-55 material to the years 1925-540 Similarly, from the 1956-65 material we estimated the incidence for only the years 1956-64.

In the course of following-up the mortality rates we noted how often diabetes was mentioned on the death certificates of these diabetics. The findings will be considered in connection with the discussion of mortality statistics as a means of estimating incidence time trends.

Table 1 Reason for detection of diabetes, by age at diagnosis and sex

\begin{tabular}{|c|c|c|c|c|c|c|c|c|c|c|c|}
\hline \multirow{3}{*}{$\operatorname{Sex}$} & \multirow{3}{*}{ Reason for detection } & \multicolumn{7}{|c|}{ Age at diagnosis (years) } & & & \multirow{3}{*}{$1925-55$} \\
\hline & & \multicolumn{2}{|c|}{$<20$} & \multicolumn{2}{|c|}{$20-49$} & \multicolumn{2}{|l|}{$>\mathbf{5 0}$} & \multirow{2}{*}{$\frac{\begin{array}{l}\text { Un- } \\
\text { known }\end{array}}{\text { No. }}$} & \multicolumn{2}{|c|}{ All ages } & \\
\hline & & No. & $\%$ & No. & $\%$ & No. & $\%$ & & No. & $\%$ & \\
\hline \multirow[t]{3}{*}{ Male } & \multirow{3}{*}{$\begin{array}{l}\text { Consulted doctor because of symptoms of diabetes } \\
\text { Coma in previously unrecognised diabetes } \\
\text { Examination in connection with some other } \\
\text { disease or injury } \\
\text { Health check } \\
\text { Other and doubtful } \\
\text { All reasons }\end{array}$} & $\begin{array}{r}66 \\
0\end{array}$ & $84 \cdot 6$ & $\begin{array}{r}87 \\
0\end{array}$ & $43 \cdot 3$ & $\begin{array}{r}300 \\
2\end{array}$ & $\begin{array}{r}32 \cdot 0 \\
0.2\end{array}$ & $\begin{array}{l}\mathbf{0} \\
\mathbf{0}\end{array}$ & $\begin{array}{r}453 \\
2\end{array}$ & $\begin{array}{r}36 \cdot 7 \\
0 \cdot 2\end{array}$ & $\begin{array}{r}49 \cdot 2 \\
0.2\end{array}$ \\
\hline & & $\begin{array}{l}4 \\
1 \\
7\end{array}$ & $\begin{array}{l}5 \cdot 1 \\
1 \cdot 3 \\
9 \cdot 0\end{array}$ & $\begin{array}{l}42 \\
34 \\
38\end{array}$ & $\begin{array}{l}20 \cdot 9 \\
16 \cdot 9 \\
18 \cdot 9\end{array}$ & $\begin{array}{r}447 \\
56 \\
132\end{array}$ & $\begin{array}{r}47 \cdot 7 \\
6 \cdot 0 \\
14 \cdot 1\end{array}$ & $\begin{array}{r}2 \\
1 \\
17\end{array}$ & $\begin{array}{r}495 \\
92 \\
194\end{array}$ & $\begin{array}{r}40 \cdot 0 \\
7 \cdot 4 \\
15 \cdot 7\end{array}$ & $\begin{array}{r}28 \cdot 1 \\
4 \cdot 9 \\
176\end{array}$ \\
\hline & & 78 & $100 \cdot 0$ & 201 & $100 \cdot 0$ & 937 & $100 \cdot 0$ & 20 & 1236 & $100 \cdot 0$ & $100 \cdot 0$ \\
\hline \multirow[t]{3}{*}{ Female } & \multirow{2}{*}{$\begin{array}{l}\text { Consulted doctor because of symptoms of diabetes } \\
\text { Coma in previously unrecognised diabetes } \\
\text { Examination in connection with some other } \\
\text { disease or injury } \\
\text { Health check } \\
\text { Other and doubtful }\end{array}$} & $\begin{array}{r}44 \\
3\end{array}$ & $\begin{array}{r}71 \cdot 0 \\
4 \cdot 8\end{array}$ & $\begin{array}{r}84 \\
1\end{array}$ & $\begin{array}{r}61 \cdot 8 \\
0.7\end{array}$ & $\begin{array}{r}594 \\
7\end{array}$ & $\begin{array}{r}42 \cdot 5 \\
0.5\end{array}$ & $\begin{array}{l}1 \\
0\end{array}$ & $\begin{array}{r}723 \\
11\end{array}$ & $\begin{array}{r}44 \cdot 5 \\
0.7\end{array}$ & $\begin{array}{r}55 \cdot 6 \\
0.8\end{array}$ \\
\hline & & $\begin{array}{l}5 \\
1 \\
9\end{array}$ & $\begin{array}{r}8 \cdot 1 \\
1 \cdot 6 \\
14 \cdot 5\end{array}$ & $\begin{array}{r}16 \\
7 \\
28\end{array}$ & $\begin{array}{r}11 \cdot 8 \\
5 \cdot 1 \\
20 \cdot 6\end{array}$ & $\begin{array}{r}563 \\
23 \\
212\end{array}$ & $\begin{array}{r}40 \cdot 2 \\
1 \cdot 6 \\
15 \cdot 2\end{array}$ & $\begin{array}{r}0 \\
1 \\
24\end{array}$ & $\begin{array}{r}584 \\
32 \\
273\end{array}$ & $\begin{array}{r}36 \cdot 0 \\
2 \cdot 0 \\
16 \cdot 8\end{array}$ & $\begin{array}{r}26 \cdot 1 \\
1 \cdot 3 \\
16 \cdot 2\end{array}$ \\
\hline & All reasons & 62 & $100 \cdot 0$ & 136 & $100 \cdot 0$ & 1399 & $100 \cdot 0$ & 26 & 1623 & $100 \cdot 0$ & $100 \cdot 0$ \\
\hline
\end{tabular}




\section{Results}

\section{CHARACTERISTICS OF THE SERIES}

Table 1 shows the 1956-65 material by sex, age, and by the reason for detection of diabetes. The percentage distribution for all ages for 1925-55 is shown for comparison. In every respect there are greater variations by age than by sex. About $85 \%$ of men below the age of 20 were diagnosed because they consulted a physician for symptoms of diabetes; for men over 50 , this figure decreased to about $30 \%$. For women the percentage varied from about $70 \%$ below the age of 20 to about $40 \%$ above the age of 50 years. More than one-third of the patients were diagnosed as a result of some other disease or injury.

If the figures for 1925-55 are compared there is a decrease in the percentage of patients of both sexes who were diagnosed because they consulted a physician for symptoms of diabetes and a corresponding increase in the percentage of patients who were discovered to be diabetics as a result of some other disease or injury (from $28 \%$ to $40 \%$ for men and $26 \%$ to $36 \%$ for women). The percentage of diabetic patients discovered by a health check was higher for 1956-65 than for 1925-55, particularly for men aged between 20 and 49. The difference is explained by the more extensive use of medical services in factories, offices, etc. during the latter period.

Table 1 suggests that some of the cases that were registered during 1956-65 might not have come to light during earlier periods of less intensive diagnostic practices.

Table 2 gives the interval between diagnosis of diabetes and first hospital admission.

The percentage of cases discovered either during the hospital stay or within the previous month was very similar for both periods. This is also true for cases diagnosed more than one year before admission. In both periods only about one-third of the cases had been diagnosed more than one month before the admission which recorded the diagnosis in the hospital records. Younger patients had shorter intervals than older. The table shows that no major change has taken place in the delay of admission to hospital of diagnosed diabetics between the two study periods.

Table 3 gives the reasons for the first admission to hospital of the diabetics.

The percentage admitted for diabetic coma or for insulin shock is remarkably similar in the two series. However, the period 1956-65 shows a much larger percentage admitted for other diseases or injuries. Conceivably, some of this difference may be owing to changes in coding procedures.

Five point four per cent of the males and $5.2 \%$ of the females had received insulin before admission and these figures were considerably larger for ages between 20 and 49 years (males $14.4 \%$ and females $15 \cdot 4 \%$ ). The corresponding figures for all ages in 1925-55 were males $9 \cdot 1 \%$ and females $6 \cdot 7 \%$.

Table 4 shows the treatment given at discharge from hospital. Below 20 years of age at diagnosis $89.5 \%$ of the males and $95 \%$ of the females were treated with insulin, compared with $13.8 \%$ and $9.2 \%$ at the age of 50 and above. For oral drugs the tendency was the opposite. As many as $13.1 \%$ of the men and $40.4 \%$ of the women in the highest age group were discharged on oral drugs, compared with $1.3 \%$ and $1.7 \%$ below the age of 20. At ages of 50 or over, half of the patients $(52.9 \%$ men and $49.9 \%$ women) were managed by 'diet only'.

For the period 1925-55 oral drugs were not available and more than half of the patients had been prescribed insulin regimen at discharge. Thus, the relationship between patients on diet alone and patients given drugs (insulin alone or insulin +

Table 2 Interval between diagnosis of diabetes and first hospital admission

\begin{tabular}{|c|c|c|c|c|c|c|c|c|c|c|c|}
\hline \multirow{3}{*}{ Sex } & \multirow{3}{*}{ Interval } & \multicolumn{7}{|c|}{ Age at diagnosis (years) } & & & \multirow{3}{*}{$1925-5$} \\
\hline & & \multicolumn{2}{|c|}{$<20$} & \multicolumn{2}{|c|}{$20-49$} & \multicolumn{2}{|l|}{$>50$} & \multirow{2}{*}{$\begin{array}{l}\begin{array}{l}\text { Un- } \\
\text { known }\end{array} \\
\text { No. }\end{array}$} & \multicolumn{2}{|c|}{ All ages } & \\
\hline & & No. & $\%$ & No. & $\%$ & No. & $\%$ & & No. & $\%$ & \\
\hline Male & $\begin{array}{l}\text { Not diagnosed before admission } \\
\text { Not more than one month } \\
\text { More than one month, not more than one year } \\
\text { More than one year } \\
\text { Doubtful } \\
\text { All intervals }\end{array}$ & $\left.\begin{array}{r}2 \\
65 \\
3 \\
8 \\
0 \\
78\end{array}\right\}$ & $\begin{array}{r}85 \cdot 9 \\
14 \cdot 1 \\
100 \cdot 0\end{array}$ & $\begin{array}{r}31 \\
83 \\
29 \\
57 \\
1 \\
201\end{array}$ & $\left\{\begin{array}{l}56 \cdot 7 \\
43 \cdot 3 \\
100 \cdot 0\end{array}\right.$ & $\begin{array}{r}374 \\
250 \\
122 \\
187 \\
4 \\
937\end{array}$ & $\begin{array}{l}66 \cdot 6 \\
33 \cdot 4 \\
100 \cdot 0\end{array}$ & $\begin{array}{r}0 \\
0 \\
0 \\
1 \\
19 \\
20\end{array}$ & $\begin{array}{r}407 \\
398 \\
154 \\
253 \\
24 \\
1236\end{array}$ & $\begin{array}{r}32 \cdot 9 \\
32 \cdot 2 \\
12 \cdot 5 \\
20 \cdot 5 \\
1 \cdot 9 \\
100 \cdot 0\end{array}$ & $\begin{array}{r}21 \cdot 4 \\
45 \cdot 1 \\
9 \cdot 5 \\
22 \cdot 8 \\
1 \cdot 2 \\
100 \cdot 0\end{array}$ \\
\hline Female & $\begin{array}{l}\text { Not diagnosed before admission } \\
\text { Not more than one month } \\
\text { More than one month, not more than one year } \\
\text { More than one year } \\
\text { Doubtful } \\
\text { All intervals }\end{array}$ & $\left.\begin{array}{r}63 \\
3 \\
10 \\
0 \\
62\end{array}\right\}$ & $\begin{array}{r}79 \cdot 0 \\
21 \cdot 0 \\
100 \cdot 0\end{array}$ & $\begin{array}{r}20 \\
57 \\
21 \\
37 \\
1 \\
136\end{array}$ & $\left\{\begin{array}{r}56 \cdot 6 \\
43 \cdot 4 \\
100 \cdot 0\end{array}\right.$ & $\begin{array}{r}485 \\
446 \\
184 \\
278 \\
6 \\
1399\end{array}$ & $\left\{\begin{array}{c}66.5 \\
33 \cdot 5 \\
100 \cdot 0\end{array}\right.$ & $\begin{array}{r}0 \\
0 \\
0 \\
26 \\
26\end{array}$ & $\begin{array}{r}511 \\
546 \\
208 \\
325 \\
33 \\
1623\end{array}$ & $\begin{array}{r}31 \cdot 5 \\
33 \cdot 6 \\
12.8 \\
20 \cdot 0 \\
2.0 \\
100 \cdot 0\end{array}$ & $\begin{array}{r}22 \cdot 3 \\
43 \cdot 4 \\
10 \cdot 3 \\
22 \cdot 6 \\
1 \cdot 4 \\
100 \cdot 0\end{array}$ \\
\hline
\end{tabular}


Table 3 Reason for first hospital admission, by age at diagnosis and sex

\begin{tabular}{|c|c|c|c|c|c|c|c|c|c|c|c|}
\hline \multirow{3}{*}{$\operatorname{Sex}$} & \multirow{3}{*}{ Reason for admission } & \multicolumn{7}{|c|}{ Age at diagnosis (years) } & & & \multirow{3}{*}{$1925-55$} \\
\hline & & \multicolumn{2}{|c|}{$<20$} & \multicolumn{2}{|c|}{$20-49$} & \multicolumn{2}{|l|}{$>50$} & \multirow{2}{*}{$\begin{array}{l}\begin{array}{l}U n- \\
\text { known }\end{array} \\
\text { No. }\end{array}$} & \multicolumn{2}{|c|}{ All ages } & \\
\hline & & No. & $\%$ & No. & $\%$ & No. & $\%$ & & No. & $\%$ & \\
\hline \multirow[t]{3}{*}{ Male } & \multirow{2}{*}{$\begin{array}{l}\text { Coma or precoma } \\
\text { Insulin shock } \\
\text { For adjustment of previously recognised diabetes } \\
\text { or other diabetic complications } \\
\text { For adjustment of recently discovered diabetes } \\
\text { Other diseases, injuries, and doubtful }\end{array}$} & $\begin{array}{l}5 \\
3\end{array}$ & $\begin{array}{l}6 \cdot 4 \\
3 \cdot 8\end{array}$ & $\begin{array}{l}6 \\
8\end{array}$ & $\begin{array}{l}3 \cdot 0 \\
4 \cdot 0\end{array}$ & $\begin{array}{r}17 \\
3\end{array}$ & $\begin{array}{l}1 \cdot 8 \\
0 \cdot 3\end{array}$ & 1 & $\begin{array}{l}29 \\
15\end{array}$ & $\begin{array}{l}2 \cdot 3 \\
1 \cdot 2\end{array}$ & $\begin{array}{l}2.8 \\
0.9\end{array}$ \\
\hline & & $\begin{array}{r}3 \\
63 \\
4\end{array}$ & $\begin{array}{r}3 \cdot 8 \\
80.8 \\
5 \cdot 1\end{array}$ & $\begin{array}{l}26 \\
94 \\
67\end{array}$ & $\begin{array}{l}12 \cdot 9 \\
46 \cdot 8 \\
33 \cdot 3\end{array}$ & $\begin{array}{r}70 \\
266 \\
581\end{array}$ & $\begin{array}{r}7.5 \\
28.4 \\
62.0\end{array}$ & $\begin{array}{r}3 \\
0 \\
15\end{array}$ & $\begin{array}{l}102 \\
423 \\
667\end{array}$ & $\begin{array}{r}8 \cdot 3 \\
34 \cdot 2 \\
54 \cdot 0\end{array}$ & $\begin{array}{l}17 \cdot 3 \\
42 \cdot 9 \\
36 \cdot 1\end{array}$ \\
\hline & All admissions & 78 & $100 \cdot 0$ & 201 & $100 \cdot 0$ & 937 & $100 \cdot 0$ & 20 & 1236 & $100 \cdot 0$ & $100 \cdot 0$ \\
\hline \multirow[t]{3}{*}{ Female } & \multirow{2}{*}{$\begin{array}{l}\text { Coma or precoma } \\
\text { Insulin shock } \\
\text { For adjustment of previously recognised diabetes } \\
\text { or other diabetic complications } \\
\text { For adjustment of recently diagnosed diabetes } \\
\text { Other diseases, injuries, and doubtful }\end{array}$} & $\begin{array}{l}8 \\
1\end{array}$ & $\begin{array}{r}12.9 \\
1.6\end{array}$ & $\begin{array}{r}13 \\
5\end{array}$ & $\begin{array}{l}9 \cdot 6 \\
3 \cdot 7\end{array}$ & $\begin{array}{r}37 \\
2\end{array}$ & $\begin{array}{l}2.6 \\
0.1\end{array}$ & $\begin{array}{l}1 \\
0\end{array}$ & $\begin{array}{r}59 \\
8\end{array}$ & $\begin{array}{l}3.6 \\
0.5\end{array}$ & $\begin{array}{l}3 \cdot 8 \\
0.3\end{array}$ \\
\hline & & $\begin{array}{r}2 \\
42 \\
9\end{array}$ & $\begin{array}{r}3 \cdot 2 \\
67 \cdot 7 \\
14 \cdot 5\end{array}$ & $\begin{array}{l}19 \\
64 \\
35\end{array}$ & $\begin{array}{l}14 \cdot 0 \\
47 \cdot 1 \\
25 \cdot 8\end{array}$ & $\begin{array}{l}102 \\
492 \\
766\end{array}$ & $\begin{array}{r}7 \cdot 3 \\
35 \cdot 2 \\
54 \cdot 7\end{array}$ & $\begin{array}{r}5 \\
0 \\
20\end{array}$ & $\begin{array}{l}128 \\
598 \\
830\end{array}$ & $\begin{array}{r}7 \cdot 9 \\
36 \cdot 8 \\
51 \cdot 2\end{array}$ & $\begin{array}{l}19 \cdot 8 \\
42.9 \\
33 \cdot 2\end{array}$ \\
\hline & All admissions & 62 & $100 \cdot 0$ & 136 & $100 \cdot 0$ & 1399 & $100 \cdot 0$ & 26 & 1623 & $100 \cdot 0$ & $100 \cdot 0$ \\
\hline
\end{tabular}

Table 4 Treatment at discharge

\begin{tabular}{|c|c|c|c|c|c|c|c|c|c|c|}
\hline \multirow{3}{*}{ Sex } & \multirow{3}{*}{ Treatment on discharge } & \multicolumn{7}{|c|}{ Age at diagnosis (years) } & & \\
\hline & & \multicolumn{2}{|c|}{$<20$} & \multicolumn{2}{|c|}{$20-49$} & \multicolumn{2}{|l|}{$\$ 50$} & \multirow{2}{*}{$\begin{array}{l}\begin{array}{l}U n- \\
\text { known }\end{array} \\
\text { No. }\end{array}$} & \multicolumn{2}{|c|}{ All ages } \\
\hline & & No. & $\%$ & No. & $\%$ & No. & $\%$ & & No. & $\%$ \\
\hline \multirow[t]{2}{*}{ Male } & $\begin{array}{l}\text { Insulin } \\
\text { Peroral drugs } \\
\text { Both insulin and peroral } \\
\text { Unknown } \\
\text { Diet only }\end{array}$ & $\begin{array}{r}68 \\
1 \\
1 \\
0 \\
6\end{array}$ & $\begin{array}{r}89 \cdot 5 \\
1 \cdot 3 \\
1 \cdot 3 \\
77 \cdot 9\end{array}$ & $\begin{array}{r}93 \\
43 \\
0 \\
0 \\
61\end{array}$ & $\begin{array}{l}47 \cdot 2 \\
21 \cdot 8 \\
\overline{31} \cdot 0\end{array}$ & $\begin{array}{r}114 \\
274 \\
1 \\
1 \\
437\end{array}$ & $\begin{array}{r}13 \cdot 8 \\
33 \cdot 1 \\
0 \cdot 1 \\
0 \cdot 1 \\
52 \cdot 9\end{array}$ & $\begin{array}{l}2 \\
4 \\
0 \\
0 \\
6\end{array}$ & $\begin{array}{r}277 \\
322 \\
2 \\
1 \\
510\end{array}$ & $\begin{array}{r}24 \cdot 9 \\
29 \cdot 0 \\
0 \cdot 2 \\
\overline{45} \cdot 9\end{array}$ \\
\hline & All treatments & 76 & $100 \cdot 0$ & 197 & $100 \cdot 0$ & 827 & $100 \cdot 0$ & 12 & 1112 & $100 \cdot 0$ \\
\hline \multirow[t]{2}{*}{ Female } & $\begin{array}{l}\text { Insulin } \\
\text { Peroral drugs } \\
\text { Both insulin and peroral } \\
\text { Unknown } \\
\text { Diet only }\end{array}$ & $\begin{array}{r}57 \\
1 \\
0 \\
0 \\
2\end{array}$ & $\begin{array}{l}95 \cdot 0 \\
1 \cdot 7 \\
\overline{3} \cdot 3\end{array}$ & $\begin{array}{r}69 \\
24 \\
1 \\
2 \\
35\end{array}$ & $\begin{array}{r}52 \cdot 7 \\
18 \cdot 3 \\
0 \cdot 8 \\
1 \cdot 5 \\
26 \cdot 7\end{array}$ & $\begin{array}{r}114 \\
502 \\
4 \\
3 \\
619\end{array}$ & $\begin{array}{r}9 \cdot 2 \\
40 \cdot 4 \\
0 \cdot 3 \\
0 \cdot 2 \\
49 \cdot 9\end{array}$ & $\begin{array}{r}2 \\
10 \\
0 \\
0 \\
6\end{array}$ & $\begin{array}{r}242 \\
537 \\
5 \\
5 \\
662\end{array}$ & $\begin{array}{r}16 \cdot 7 \\
37 \cdot 0 \\
0 \cdot 3 \\
0 \cdot 3 \\
45 \cdot 6\end{array}$ \\
\hline & All treatments & 60 & $100 \cdot 0$ & 131 & $100 \cdot 0$ & 1242 & $100 \cdot 0$ & 18 & 1451 & $100 \cdot 0$ \\
\hline
\end{tabular}

oral drugs) was practically the same for both periods.

\section{EFFECT OF PROLONGED REGISTRATION PERIOD ON INCIDENCE BY YEAR OF DIAGNOSIS}

As mentioned there were 246 patients discharged in 1956-65 who had been diagnosed in 1955 or earlier. This number should be seen in relation to the 4251 patients recorded for 1925-55.

Of these 237 were diagnosed in the period 1925-54-that is, during the years that Westlund studied incidence rates. We have added these cases to his in the appropriate subgroups and revised the incidence rates. No major changes were observed. In particular, few new cases were diagnosed during the second world war, so that the dramatic reduction in incidence shown in the paper by Westlund (1966) is not affected. Table 5 shows the incidence for the most recent of Westlund's periods (1951-55), with and without
Table 5 Incidence of diabetes diagnosed during 1951-54 with and without adding cases from the 1956-65 hospital material

\begin{tabular}{|c|c|c|c|c|}
\hline \multirow{2}{*}{$\begin{array}{l}\text { Age at } \\
\text { diagnosis } \\
\text { (years) }\end{array}$} & \multicolumn{2}{|c|}{$\begin{array}{l}\text { Males } \\
\text { (based on discharges) }\end{array}$} & \multicolumn{2}{|c|}{$\begin{array}{l}\text { Females } \\
\text { (based on discharges) }\end{array}$} \\
\hline & $1951-55$ & $1956-65$ & $1951-55$ & $1965-65$ \\
\hline $\begin{array}{r}<10 \\
10-19 \\
20-29 \\
30-39 \\
40-49 \\
50-59 \\
60-69 \\
70-79\end{array}$ & $\begin{array}{r}0.7 \\
0.7 \\
1.2 \\
1.5 \\
2.7 \\
6.9 \\
12.8 \\
16.1\end{array}$ & $\begin{array}{r}0.7 \\
0.7 \\
1.2 \\
1.8 \\
3.2 \\
7.8 \\
15.5 \\
17.6\end{array}$ & $\begin{array}{r}0.6 \\
1.1 \\
0.4 \\
1.0 \\
1.0 \\
5.1 \\
14.0 \\
25.4\end{array}$ & $\begin{array}{r}0.6 \\
1.3 \\
0.4 \\
1.1 \\
1.2 \\
6.0 \\
16.8 \\
28.2\end{array}$ \\
\hline $80+$ & $24 \cdot 4$ & $25 \cdot 6$ & $28 \cdot 4$ & $29 \cdot 5$ \\
\hline
\end{tabular}

the cases discovered by means of the 1956-65 hospitalisation. At ages between 30 and 70 years the prolonged registration increased the incidence by roughly $15 \%$ to $20 \%$. At younger and older ages the effect was less pronounced. 
INCIDENCE TIME TREND

As in the previous study we assumed that cases diagnosed during the last year of the registration period-that is, 1965-were too incomplete to provide useful incidence estimates. We therefore present estimates for the periods $1956-60$ and 1961-64, to be compared primarily with the periods 1946-50 and 1951-54 as given in the previous report (without adding the 1946-54 cases discovered in the present survey).

Table 6 shows incidence per 10000 population in these four periods by age and sex. The rates are irregular because of the small number of cases in each subgroup.

The main impression is that there has been a fairly constant incidence, certainly very different from that found for cardiovascular disease in Oslo after the second world war (Westlund, 1966). However two features deserve comment: an increase for boys and girls younger than 10-19 years, and a decrease for women aged between 40 and 59. The decrease in middle-aged women was observed previously; in 1931-35 the incidence for women aged between 50 and 59 was 11.9 per 10000 compared to the 1961-64 rate of 4.1. Data are not available to relate these figures to changes in pregnancy patterns or body weight.

The apparent increase in younger people is analysed in Table 7 which compares the entire period 1925-54 with 1956-64, by five-year age groups. In children under 10 the incidence in the latter period has nearly doubled. At ages between 15 and 29 years the differences are small.

We have considered the various sources of error in this comparison, but conclude that the most likely explanation is that after 1950 there has been a real increase in the incidence of diabetes in children. Better medical and obstetric care would gradually tend to save relatively more infants who are genetically determined to get diabetes, but it is hardly probable that this will have affected the incidence rates for children under 10 years in the observed period. Of course, new environmental factors (viruses) may be a factor, but this cannot be elucidated from our material. Children at earlier periods may have been misdiagnosed or possibly were not seen by doctors at all and deaths reported as caused by pneumonia or ill-defined diseases.

Two other studies on children below 15 years of age were carried out with a similar technique. Bratlid (1976) collected data on children younger than 15 years in the three most northern countries of Norway for the years 1966-74, and found a yearly incidence per 10000 of 0.92 for boys and 0.66 for girls, compared with 1.2 for boys and 0.95

Table 6 Diabetes incidence per 10000 a year, by age and sex in different quinquennia

\begin{tabular}{|c|c|c|c|c|c|c|c|c|c|c|c|c|c|c|c|c|c|}
\hline \multirow{3}{*}{$\frac{\text { Sex }}{\text { Men }}$} & \multirow{3}{*}{$\begin{array}{l}\text { Quinquennium } \\
\text { of diagnosis } \\
1946-50 \\
1951-54 \\
1956-60 \\
1961-64 \\
\text { Rates 1956-64 in } \\
\text { percentage of } \\
\text { rates 1946-54 }\end{array}$} & \multicolumn{16}{|c|}{ Age at diagnosis (years) } \\
\hline & & \multicolumn{2}{|l|}{$<10$} & \multicolumn{2}{|c|}{$10-19$} & \multicolumn{2}{|c|}{$20-29$} & \multicolumn{2}{|c|}{$30-39$} & \multicolumn{2}{|c|}{$40-49$} & \multicolumn{2}{|c|}{$50-59$} & \multicolumn{2}{|l|}{$60-69$} & \multicolumn{2}{|l|}{$70-79$} \\
\hline & & $\begin{array}{l}0.5 \\
0.7 \\
1.4 \\
0.9\end{array}$ & $\begin{array}{l}(6) \\
(8) \\
(20) \\
(11)\end{array}$ & $\begin{array}{l}0 \cdot 7 \\
0 \cdot 7 \\
1 \cdot 3 \\
1 \cdot 3\end{array}$ & $\begin{array}{r}(7) \\
(6) \\
(19) \\
(16)\end{array}$ & $\begin{array}{l}1 \cdot 2 \\
1 \cdot 2 \\
1 \cdot 3 \\
0 \cdot 7\end{array}$ & $\begin{array}{l}(19) \\
(14) \\
(17) \\
(8)\end{array}$ & $\begin{array}{l}2 \cdot 1 \\
1 \cdot 8 \\
1 \cdot 5 \\
1 \cdot 2 \\
0 \cdot 61\end{array}$ & $\begin{array}{l}(35) \\
(25) \\
(25) \\
(14)\end{array}$ & $\begin{array}{l}2 \cdot 6 \\
3 \cdot 2 \\
2 \cdot 5 \\
3 \cdot 0\end{array}$ & $\begin{array}{l}(42) \\
(43) \\
(41) \\
(41)\end{array}$ & $\begin{array}{l}6 \cdot 8 \\
7 \cdot 8 \\
6 \cdot 8 \\
6 \cdot 9\end{array}$ & $\begin{array}{c}(86) \\
(88) \\
(105) \\
(86)\end{array}$ & $\begin{array}{l}13 \cdot 6 \\
15 \cdot 5 \\
17 \cdot 3 \\
12 \cdot 3\end{array}$ & $\begin{array}{r}(93) \\
(103) \\
(189) \\
(121)\end{array}$ & $\begin{array}{l}15 \cdot 1 \\
17 \cdot 6 \\
21 \cdot 7 \\
19 \cdot 8\end{array}$ & $\begin{array}{l}(54) \\
(58) \\
(99) \\
(86)\end{array}$ \\
\hline Women & $\begin{array}{l}1946-50 \\
1951-54 \\
1956-60 \\
1961-64 \\
\text { Rates 1956-64 in } \\
\text { percentage of } \\
\text { rates 1946-54 }\end{array}$ & $\begin{array}{l}0.3 \\
0.6 \\
0.7 \\
1 \cdot 1\end{array}$ & $\begin{array}{r}(4) \\
(7) \\
(9) \\
(12)\end{array}$ & $\begin{array}{l}1.3 \\
1.3 \\
0.9 \\
0.9\end{array}$ & $\begin{array}{l}(13) \\
(12) \\
(14) \\
(12)\end{array}$ & $\begin{array}{l}0.8 \\
0.4 \\
0.8 \\
0.6\end{array}$ & $\begin{array}{r}(16) \\
(5) \\
(12) \\
(8)\end{array}$ & $\begin{array}{l}0.8 \\
1 \cdot 1 \\
0.8 \\
0.6\end{array}$ & $\begin{array}{l}(17) \\
(16) \\
(14) \\
(7)\end{array}$ & $\begin{array}{l}2 \cdot 2 \\
1 \cdot 2 \\
1 \cdot 9 \\
1 \cdot 8\end{array}$ & $\begin{array}{l}(46) \\
(21) \\
(38) \\
(28)\end{array}$ & $\begin{array}{l}8 \cdot 5 \\
6 \cdot 0 \\
5 \cdot 2 \\
4 \cdot 1\end{array}$ & $\begin{array}{r}(131) \\
(84) \\
(103) \\
(65)\end{array}$ & $\begin{array}{l}16 \cdot 4 \\
16 \cdot 8 \\
16 \cdot 3 \\
12 \cdot 0\end{array}$ & $\begin{array}{l}(160) \\
(154) \\
(235) \\
(163)\end{array}$ & $\begin{array}{l}21 \cdot 6 \\
28 \cdot 2 \\
28 \cdot 7 \\
28 \cdot 2\end{array}$ & $\begin{array}{l}(125) \\
(150) \\
(218) \\
(192)\end{array}$ \\
\hline
\end{tabular}

No. of patients diagnosed is given in parentheses

Table 7 Diabetes incidence per 10000 a year, 1925-54 and 1956-64 in five-year diagnostic age groups below 30 years, by sex

\begin{tabular}{|c|c|c|c|c|c|c|c|c|c|c|}
\hline \multirow{2}{*}{$\begin{array}{l}\text { Age at } \\
\text { Diagnosis } \\
\text { (years) }\end{array}$} & \multicolumn{5}{|l|}{ Males } & \multicolumn{5}{|l|}{ Females } \\
\hline & $1925-5$ & & 1956 & & $\begin{array}{l}\text { Rates } 1956-64 \\
\text { in percentage of } \\
\text { rates } 1925-54\end{array}$ & $1925-54$ & & 1956 & & $\begin{array}{l}\text { Rates } 1956-64 \\
\text { in percentage of } \\
\text { rates } 1925-54\end{array}$ \\
\hline $\begin{array}{r}0-4 \\
5-9 \\
10-14 \\
15-19 \\
20-24 \\
25-29\end{array}$ & $\begin{array}{l}0.31 \\
0.86 \\
0.94 \\
1.06 \\
0.83 \\
1.01\end{array}$ & $\begin{array}{l}(12) \\
(29) \\
(30) \\
(41) \\
(38) \\
(57)\end{array}$ & $\begin{array}{l}0.67 \\
1 \cdot 63 \\
1 \cdot 32 \\
1 \cdot 19 \\
0.96 \\
1 \cdot 12\end{array}$ & $\begin{array}{l}(9) \\
(21) \\
(18) \\
(16) \\
(12) \\
(14)\end{array}$ & $\begin{array}{l}2 \cdot 16 \\
1 \cdot 90 \\
1 \cdot 40 \\
1 \cdot 12 \\
1 \cdot 03 \\
1 \cdot 11\end{array}$ & $\begin{array}{l}0.16 \\
0.54 \\
0.89 \\
1 \cdot 15 \\
0.59 \\
0.78\end{array}$ & $\begin{array}{l}(6) \\
(18) \\
(28) \\
(48) \\
(37) \\
(48)\end{array}$ & $\begin{array}{l}0.24 \\
1.45 \\
1 \cdot 14 \\
0.77 \\
0.74 \\
0.52\end{array}$ & $\begin{array}{l}(3) \\
(18) \\
(15) \\
(11) \\
(11) \\
(9)\end{array}$ & $\begin{array}{l}1 \cdot 50 \\
2 \cdot 69 \\
1 \cdot 28 \\
0.67 \\
1 \cdot 25 \\
0.67\end{array}$ \\
\hline
\end{tabular}

No. of patients diagnosed is given in parentheses 
for girls in our study. Taking into account the difference in period and geographical area, and the small number of cases, Bratlid's figures may be said to tally fairly well with ours. The British Diabetic Association sponsored a study (Bloom et al., 1975) of all new cases of diabetes notified in children aged between 10 and 15 years in Great Britain and Ireland for a two-year period starting in November 1972. Notification suggested that there was a minimum yearly incidence of 0.77 per 10000 -that is, a figure on about the same level as the figures obtained in Oslo and in northern Norway.

\section{Mortality trends}

These are difficult to interpret, even if-as in Norway-statistics are provided not only for underlying cause but for associated causes as well. Table 8 shows the trend for $1951-70$ for ages above 25 in Norway as a whole (Central Bureau of Statistics of Norway, 1947). In contrast to what was found in Oslo, there is an increase in incidence in men aged between 35 and 64 . The increase is principally found for associated causes, however, and may therefore to a large extent be a reflection of the increase in cardiovascular mortality in this period. More difficult to reconcile with these findings is that there is no decrease in mortality for middle-aged women. In fact, diabetes as a certified associated cause of death shows an increase between 1951 and 1970 in women aged between 55 and 64 .

The tendency towards an increase in diabetes as an associated cause of death shown in Table 8 does not appear (at least from experience in Oslo) to be a result of better notification-that is, a more frequent entry of diabetes on the certificate when the diagnosis has in fact been made. Westlund found by following-up his 1925-55 material until
1961 that diabetes was mentioned on $67.5 \%$ of the certificates. But in the present study, when following-up our 1956-65 material until 1973, we found diabetes mentioned on only $52.6 \%$ of the certificates.

No obvious explanation for this difference has been found. It is possible that physicians when filling in death certificates more often left diabetes out in the latter calendar period. They may not have known that the patient suffered from diabetes, or they may have regarded as negligible a diabetes accompanying a more fatal disease. From being commonly regarded as a serious disease in itself, diabetes may in the course of later years more and more have been looked upon as relatively innocent. To be a 'diabetic' may no longer imply the risk that was linked to it in earlier years. This may possibly have influenced the tendency of physicians to omit diabetes as a subsidiary cause of death on the certificate, particularly as cardiovascular disease has come more to the fore.

It is obvious that by combining hospital records for 1956-65 with death certificates we have been able to identify many more patients with $\stackrel{\leftrightarrow}{\stackrel{\oplus}{\circ}}$ diabetes than we would have done by relying on $\mathbb{Q}$ death certificates alone. This experience tallies well with the findings of Tokuhata et al. (1975) in a one-year study in Pennsylvania. Nearly $8 \%$ \% of patients with no mention of diabetes on the death certificates were shown, by collecting informa-을 tion from physicians, to have diabetes.

\section{Conclusions}

As far as we can interpret, our data show the incidence of diabetes has doubled in children in Oslo between 1925-54 and 1956-64. At the same time the incidence in middle-aged women appears to have

Table 8 Deaths in which diabetes mellitus was cause (per 100000 population)

\begin{tabular}{|c|c|c|c|c|c|c|c|c|c|c|c|c|}
\hline \multirow{2}{*}{ Annual average } & \multicolumn{6}{|l|}{ Men } & \multicolumn{6}{|c|}{ Women } \\
\hline & $\begin{array}{l}25-34 \\
\text { years }\end{array}$ & $\begin{array}{l}35-44 \\
\text { years }\end{array}$ & $\begin{array}{l}45-54 \\
\text { years }\end{array}$ & $\begin{array}{l}55-64 \\
\text { years }\end{array}$ & $\begin{array}{l}65-74 \\
\text { years }\end{array}$ & $\begin{array}{l}75 \text { years } \\
\text { and over }\end{array}$ & $\begin{array}{l}25-34 \\
\text { years }\end{array}$ & $\begin{array}{l}35-44 \\
\text { years }\end{array}$ & $\begin{array}{l}45-54 \\
\text { years }\end{array}$ & $\begin{array}{l}55-64 \\
\text { years }\end{array}$ & $\begin{array}{l}65-74 \\
\text { years }\end{array}$ & $\begin{array}{l}75 \text { years } \\
\text { and over }\end{array}$ \\
\hline $\begin{array}{l}1951-55 \\
\text { Underlying cause of death } \\
\text { Associated cause of death } \\
\text { Both }\end{array}$ & $\begin{array}{l}3 \cdot 9 \\
1 \cdot 0 \\
4 \cdot 9\end{array}$ & $\begin{array}{l}3 \cdot 4 \\
1 \cdot 1 \\
4 \cdot 5\end{array}$ & $\begin{array}{l}3 \cdot 9 \\
5 \cdot 0 \\
8 \cdot 9\end{array}$ & $\begin{array}{r}9 \cdot 0 \\
23 \cdot 6 \\
32 \cdot 6\end{array}$ & $\begin{array}{l}25 \cdot 9 \\
66 \cdot 0 \\
91 \cdot 9\end{array}$ & $\begin{array}{r}56 \cdot 9 \\
160 \cdot 4 \\
217 \cdot 3\end{array}$ & $\begin{array}{l}2 \cdot 3 \\
0 \cdot 6 \\
2 \cdot 9\end{array}$ & $\begin{array}{l}1 \cdot 9 \\
1 \cdot 3 \\
3 \cdot 2\end{array}$ & $\begin{array}{l}2 \cdot 9 \\
2 \cdot 3 \\
5 \cdot 2\end{array}$ & $\begin{array}{l}11 \cdot 6 \\
22 \cdot 2 \\
33 \cdot 8\end{array}$ & $\begin{array}{r}35 \cdot 5 \\
108 \cdot 2 \\
143 \cdot 7\end{array}$ & $\begin{array}{r}76 \cdot 3 \\
219 \cdot 2 \\
295 \cdot 5\end{array}$ \\
\hline $\begin{array}{l}1956-60 \\
\text { Underlying cause of death } \\
\text { Associated cause of death } \\
\text { Both }\end{array}$ & $\begin{array}{l}4 \cdot 1 \\
1 \cdot 3 \\
5 \cdot 4\end{array}$ & $\begin{array}{l}3 \cdot 7 \\
1 \cdot 8 \\
5 \cdot 5\end{array}$ & $\begin{array}{r}4 \cdot 5 \\
6 \cdot 9 \\
11 \cdot 4\end{array}$ & $\begin{array}{r}9 \cdot 2 \\
25 \cdot 0 \\
34 \cdot 2\end{array}$ & $\begin{array}{r}23 \cdot 6 \\
101 \cdot 7 \\
125 \cdot 3\end{array}$ & $\begin{array}{r}49 \cdot 7 \\
220 \cdot 3 \\
270 \cdot 0\end{array}$ & $\begin{array}{l}2 \cdot 9 \\
0 \cdot 5 \\
3 \cdot 4\end{array}$ & $\begin{array}{l}2 \cdot 2 \\
0 \cdot 9 \\
3 \cdot 1\end{array}$ & $\begin{array}{l}2 \cdot 6 \\
2 \cdot 9 \\
5 \cdot 5\end{array}$ & $\begin{array}{r}9 \cdot 1 \\
26 \cdot 3 \\
25 \cdot 4\end{array}$ & $\begin{array}{r}37 \cdot 5 \\
118 \cdot 8 \\
156 \cdot 3\end{array}$ & $\begin{array}{r}82 \cdot 8 \\
324 \cdot 9 \\
407 \cdot 7\end{array}$ \\
\hline $\begin{array}{l}1961-65 \\
\text { Underlying cause of death } \\
\text { Associated cause of death } \\
\text { Both }\end{array}$ & $\begin{array}{l}4 \cdot 3 \\
1 \cdot 2 \\
5 \cdot 5\end{array}$ & $\begin{array}{l}5 \cdot 8 \\
2 \cdot 1 \\
7 \cdot 9\end{array}$ & $\begin{array}{r}5 \cdot 6 \\
7 \cdot 8 \\
13 \cdot 4\end{array}$ & $\begin{array}{r}9 \cdot 0 \\
33 \cdot 1 \\
42 \cdot 1\end{array}$ & $\begin{array}{r}24 \cdot 5 \\
126 \cdot 6 \\
151 \cdot 1\end{array}$ & $\begin{array}{r}74 \cdot 8 \\
321 \cdot 6 \\
396 \cdot 4\end{array}$ & $\begin{array}{l}2 \cdot 9 \\
0 \cdot 4 \\
3 \cdot 3\end{array}$ & $\begin{array}{l}2 \cdot 5 \\
1 \cdot 8 \\
4 \cdot 3\end{array}$ & $\begin{array}{l}3 \cdot 2 \\
3 \cdot 7 \\
6 \cdot 9\end{array}$ & $\begin{array}{r}9 \cdot 4 \\
32 \cdot 8 \\
42 \cdot 2\end{array}$ & $\begin{array}{r}35 \cdot 0 \\
171 \cdot 5 \\
206 \cdot 5\end{array}$ & $\begin{array}{r}99 \cdot 5 \\
431 \cdot 7 \\
531 \cdot 2\end{array}$ \\
\hline $\begin{array}{l}\text { 1966-70 } \\
\text { Underlying cause of death } \\
\text { Associated cause of death } \\
\text { Both }\end{array}$ & $\begin{array}{l}2 \cdot 2 \\
1 \cdot 2 \\
3 \cdot 4\end{array}$ & $\begin{array}{l}5 \cdot 4 \\
3 \cdot 6 \\
9 \cdot 0\end{array}$ & $\begin{array}{r}4 \cdot 6 \\
8 \cdot 5 \\
13 \cdot 1\end{array}$ & $\begin{array}{r}7 \cdot 9 \\
42 \cdot 3 \\
50 \cdot 2\end{array}$ & $\begin{array}{r}21 \cdot 7 \\
169 \cdot 5 \\
191 \cdot 2\end{array}$ & $\begin{array}{r}62 \cdot 8 \\
427.8 \\
490.6\end{array}$ & $\begin{array}{l}2 \cdot 4 \\
0 \cdot 3 \\
2 \cdot 7\end{array}$ & $\begin{array}{l}2 \cdot 0 \\
1 \cdot 5 \\
3 \cdot 5\end{array}$ & $\begin{array}{l}2 \cdot 7 \\
6 \cdot 0 \\
8 \cdot 7\end{array}$ & $\begin{array}{r}7 \cdot 9 \\
34 \cdot 5 \\
42 \cdot 4\end{array}$ & $\begin{array}{r}25 \cdot 3 \\
186 \cdot 0 \\
211 \cdot 3\end{array}$ & $\begin{array}{r}70 \cdot 0 \\
534 \cdot 3 \\
604 \cdot 3\end{array}$ \\
\hline
\end{tabular}


decreased. In view of difficulties in methods however, artefacts cannot be completely excluded, and mortality data for Norway as a whole do not support the incidence findings in middle-aged women.

Reprints from H. J. Ustvedt, The Life Insurance Companies' Institute for Medical Statistics at the Oslo City Hospitals, Ulleval Sykehus, Oslo, Norway.

\section{References}

Bloom, A., Hayes, T. M., and Gamble, D. R. (1975). Register of newly diagnosed diabetic children. British Medical Journal, 3, 580-583.

Bratlid, D. (1976). Report No. 15, pp. 54-57. Nordic Council for Arctic Medical Research: Odense, Denmark. Central Bureau of Statistics of Norway (1947). Mortality Trend and Mortality Pattern 1951/70, p.100. Central Bureau of Statistics: Oslo.

Tokuhata, G. K., Miller, W., Digon, E., and Hartman, Th. (1975). Diabetes mellitus: An underestimated public health program. Journal of Chronic Diseases, 28, 23-35.

Westlund, K. (1966). Incidence of diabetes mellitus in Oslo, Norway 1925-1954. Report No. 11 of the Life Insurance Companies' Institute for Medical Statistics at the Oslo City Hospitals. British Journal of Preventive and Social Medicine, 20, 105-116. 